\title{
PERGESERAN PENYELENGGARAAN PEMERINTAHAN DAERAH BERDASARKAN KEWENANGAN KEPALA DAERAH DAN DPRD DARI ORDE BARU SAMPAI REFORMASI
}

\author{
Rizki Ramadhan, Program Studi Magister Ilmu Hukum Sekolah Pascasarjana \\ Universitas Muhammadiyah Surakarta, Email: ramaraizmadali89@gmail.com
}

doi: https://doi.org/10.24843/KS.2020.v08.i12.p07

\begin{abstract}
ABSTRAK
Tulisan ini bertujuan untuk mengkaji perubahan atas undang-undang tentang pemerintahan daerah yang dimana adanya pergeseran kewenangan Kepala Daerah dan DPRD semenjak pemerintahan orde baru sampai reformasi, dengan menggunakan teori hukum Separation Of Power dan Distribution Of Power sebagai pisau analisis berdasarkan metode penelitian hukum yuridis normatif. Hasil studi menunjukkan bahwa perundang-undangan tentang pemerintahan daerah ternyata telah mengalami lima kali pergantian dan dua kali perubahan atas undang-undang terbaru yang dampaknya berpengaruh terhadap pelayanan di masyarakat. Atas hal tersebut diketahui bahwa pergeseran atas penyelenggaraan pemerintahan daerah atas kewenangan Kepala Daerah dan DPRD ini dipengaruhi beberapa faktor, diantaranya yaitu faktor daerah, kepentingan, dan kebijakan politik dari setiap zaman.
\end{abstract}

Kata Kunci : Pergeseran Kewenangan, Kepala Daerah, DPRD.

\begin{abstract}
This paper aims to examine changes to the law on regional governance where there has been a shift in the authority of the Regional Head and DPRD from the New Order government to reform, using the legal theory of Separation of Power and Distribution of Power as an analysis knife based on normative juridical legal research methods. The results of the study show that the legislation on regional government has actually undergone five changes and two changes to the latest law which has an impact on services in society. Based on this, it is known that the shift in the administration of regional government to the authority of the Regional Head and DPRD is influenced by several factors, including regional factors, interests, and political policies from every era.
\end{abstract}

Keywords: Shifting of Authority, Regional Head, and DPRD. 


\section{Pendahuluan}

\subsection{Latar Belakang Masalah}

Plato menyatakan bahwa penyelenggaraan negara yang baik adalah yang berdasarkan pada pengaturan (hukum) yang baik. ${ }^{1}$ Keberadaan konstitusi dalam suatu negara adalah mutlak (conditio sine quanon), karena tujuan dari kehadiran konstitusi adalah untuk memberikan perlindungan terhadap hak asasi manusia. Indonesia adalah negara hukum, maka aspek kehidupan bermasyarakat, berbangsa, dan bernegara termasuk dalam penyelenggaraan pemerintahan harus berdasarkan hukum yang berlaku. Hukum pada pokoknya adalah produk pengambilan keputusan ditetapkan oleh fungsi-fungsi kekuasaan negara yang mengikat subjek hukum dengan hak-hak dan kewajiban hukum berupa larangan (prohibere), atau keharusan (obligatere), ataupun kebolehan (permittere). ${ }^{2}$ Indonesia menganut sistem pemisahan kekuasaan (separation of power) dan pembagian kekuasaan (distribution of power) diketahui bahwa doktrin pemisahan dan pembagian kekuasaan sebenarnya merupakan amanat dari amandemen UUD 1945.

Pemikir klasik seperti John Locke, Montesquieu, dan Von Vollenhoven memberikan gambaran tentang kekuasaan yang memiliki satu tujuan, yakni untuk menghindari kekuasaan yang absolut dengan menerapkan prinsip check and balance antar lembaga negara melalui konstitusi yang sekarang kita kenal dengan pemisahan kekuasaan negara yang terbagi kekuasaan legislatif, kekuasaan eksekutif, dan kekuasaan yudikatif. Dalam perjalanan pemerintahan di Indonesia terjadi beberapa kali perubahan sistem ketatanegaraan. Pasca reformasi terjadi perdebatan yang tidak kalah penting tentang pemerintahan daerah yaitu kembalinya isu kedudukan DPRD dan Kepala Daerah. Saat ini kewenangan dari DPRD dipertanyakan, apakah DPRD didudukkan secara tegas sebagai lembaga (badan) legislatif sebagaimana dikenal dalam konsep trias politica ataukah diposisikan sebagai salah satu unsur penyelenggara pemerintahan daerah. ${ }^{3}$ Pergeseran kedudukan DPRD dari Badan Legislatif Daerah menjadi unsur penyelenggara pemerintahan daerah tentu didasarkan atas perspektif diatur dalam Undang-Undang Nomor 32 Tahun 2004. Pertama, menurut para perumus, dalam sistem negara kesatuan (unitarian state) tidak dikenal badan legislatif di tingkat daerah dan badan legsilatif hanya berada di tingkat nasional. Oleh karena itu, DPRD bukan lembaga legislatif daerah. Kedua, karena DPRD bukan lembaga legislatif daerah, DPRD harus didudukkan sebagai salah satu unsur penyelenggara pemerintahan daerah.

Fungsi DPRD baik di tingkat Provinsi, Kabupaten/Kota tidak memiliki kewenangan untuk membentuk peraturan perundang-undangan yang memiliki ruang lingkup secara nasional seperti undang-undang. DPRD hanya memiliki kewenangan dalam hal pembentukan Peraturan Daerah (Perda) yang terbatas di daerah tersebut. Melihat teori Separation Of Power dan Distribution Of Power sebagai pisau analisis maka DPRD tidak dapat dikatakan sebagai lembaga legislatif, dan diperkuat dalam UndangUndang Nomor 23 Tahun 2014 tentang Pemerintahan Daerah. Berdasarkan Prinsip

${ }^{1}$ Nurul Qamar. Hak Asasi Manusia dalam Negara Hukum Demokrasi, Sinar Grafika, Jakarta Timur, hlm. 24.

2 Jimly Asshiddiqie, Perihal Undang-Undang, Rajawali Pres, Jakarta, 2011, hlm. 7.

3 Ari Dwipayana, Arah dan Agenda Reformasi DPRD: Memperkuat Kedudukan dan Kewenangan Dewan Perwakilan Rakyat Daerah, (Jakarta: USAID, 2008), hlm. 20. 
good governance dalam proses penyelenggaraan pemerintahan daerah merupakan sebuah tuntutan bagi pemerintah daerah dalam rangka mewujudkan pemerintahan yang demokratis, bersih, transparan, dapat di pertanggungjawabkan, efektif dan efisien. ${ }^{4}$ Good governance juga merupakan wujud nyata dalam penyelenggaraan Pemerintahan Negara yang bersih atau tata kelola yang baik dan benar. ${ }^{5}$ Paul Spicker, menjelaskan welfare state tidak hanya mencakup deskripsi cara pengorganisasian kesejahteraan (welfare) atau pelayanan sosial (social services), tetapi juga konsep normatif bahwa setiap orang harus memperoleh pelayanan sosial sebagai haknya. ${ }^{6}$

Berbeda dengan penyelenggaraan pemerintahan di pusat yang terdiri dari lembaga eksekutif, legislatif, dan yudikatif, penyelenggaraan Pemerintahan Daerah dilaksanakan oleh Kepala Daerah dan DPRD yang berkedudukan sebagai unsur penyelenggara pemerintahan daerah yang diberi mandat oleh rakyat melalui pemilihan langsung. Menarik untuk diamati dalam perjalanannya peraturan perundang-undangan tentang pemerintahan daerah mengalami dinamika yang sangat dinamis dan dipengaruhi oleh beberapa faktor diantaranya yaitu faktor daerah, kepentingan, dan kebijakan politik dari setiap zaman. Politik kebangsaan yang dimana sampai hari ini undang-undang tentang Pemerintahan Daerah nyatanya sudah mengalami lima kali pergantian dan dua kali perubahan atas undang-undang terbaru yang dampaknya tentu berpengaruh terhadap pelayanan masyarakat di daerah.

\subsection{Rumusan Masalah}

Berdasarkan latar belakang yang sudah dijelaskan, permasalahan yang akan dibahas adalah Bagaimana pergeseran penyelenggaraan pemerintahan daerah berdasarkan kewenangan Kepala Daerah dan DPRD dari orde baru sampai reformasi ?

\subsection{Tujuan Penulisan}

Tujuan penulisan jurnal ilmiah ini mengkaji secara kritis terhadap perubahan atas undang-undang tentang pemerintahan daerah yang dimana adanya pergeseran kewenangan Kepala Daerah dan DPRD semenjak pemerintahan orde baru sampai reformasi, dengan menggunakan teori hukum Separation Of Power dan Distribution Of Power sebagai pisau analisis dan diharapkan pembaca dapat secara mudah memahami tentang perubahan dan perkembangan tentang penyelenggaraan pemerintahan daerah.

\section{Metode Penelitian}

Penelitian ini termasuk jenis penelitian hukum yuridis normatif, karena yang diteliti adalah aspek teoritis hukum tertulis. Pendekatannya melalui normatif dengan menggunakan teori hukum. Jenis penelitian deskriptif analitis yang meliputi isi dan struktur hukum positif. Data yang digunakan adalah data sekunder berupa dokumen

4 Yulia Neta, Model Tata Kelola Administrasi Pemerintahan Yang Baik di Daerah Otonom Baru, Fiat Justitia Jurnal Ilmu Hukum, Vol. 6 No. 2, Agustus, 2012, hlm. 2.

5 Jopinus Saragih. G, Reformasi Aparatur Negara Untuk Melaksanakan Tata Kelola Pemerintahan Yang Baik Dan Benar (Good Governance), Majalah Ilmiah Widya, Vol. 29 No. 319, April, 2012, hlm. 18.

${ }^{6}$ Ahmad Dahlan dan Santosa Irfan, Menggagas Negara Kesejahteraan, Jurnal el-Jizya, Vol. II No. 1 Januari-Juni, 2014, hlm. 4. 
tertulis yang diperoleh melalui penelusuran kepustakaan. Teknik pengumpulan data menggunakan bahan hukum primer bersumber dari peraturan perundang-undangan dan bahan hukum sekunder meliputi buku-buku dan jurnal. ${ }^{7}$ Teknik data penelitian ilmiah ini bersumber dari studi dokumen dan studi kepustakaan, data yang digunakan untuk menganalisis menggunakan analisis kualitatif. Metode analisis yang digunakan induksi-interpretasi-konseptualisasi dengan menggunakan model interaktif, yaitu reduksi data, penyajian data, dan penarikan kesimpulan.

\section{Hasil dan Pembahasan}

\subsection{Pergeseran Penyelenggaraan Pemerintahan Daerah Berdasarkan Kewenangan Kepala Daerah Dan DPRD Dari Orde Baru Sampai Reformasi}

Desentralisasi merupakan pelimpahan kekuasaan dan kewenangan dari pusat ke daerah dimana kewenangan tersebut bersifat otonom yang dilaksanakan oleh pemerintahan daerah tanpa ada intervensi dari pusat. ${ }^{8}$ Pasal 18 ayat (1) UUD 1945 bahwa Negara Kesatuan Republik Indonesia terdiri dari daerah-daerah Provinsi, dan Kabupaten/Kota dan mempunyai pemerintahan daerah yang diatur dengan undangundang. Oleh karenanya, pelaksanaan fungsi pemerintahan oleh Pemerintah Daerah berupa kebijakan daerah adalah satu kesatuan yang bersifat integral dengan pemerintahan pusat atau nasional. ${ }^{9}$ Dalam Pasal 1 Angka 6 Undang-Undang Nomor 23 Tahun 2014 tentang Pemerintahan Daerah yang menyatakan bahwa otonomi daerah merupakan hak, wewenang dan kewajiban daerah otonom untuk mengatur dan mengurus sendiri urusan pemerintahan dan kepentingan masyarakat. Pada era orde baru konsep negara kesatuan cenderung ditafsirkan identik dengan sentralisasi kekuasaan dan uniformitas struktur pemerintahan. Konsekuensinya, otonomi daerah menjadi suatu yang niscaya. Daerah tidak memiliki kemerdekaan untuk menentukan masa depannya dan tidak memiliki keleluasaan untuk mengelola daerah. ${ }^{10}$ Perjalanan Pasal 18 UUD NRI 1945 nyatanya mengalami tarik menarik kepentingan dalam kehidupan bernegara, hal ini merupakan sejarah hukum yang perlu digali dan diperdalam keilmuanya untuk semangat checks and balance system dalam proposional sistem ketatanegaraan. Hukum itu bukan merupakan tujuan, akan tetapi hanya merupakan jembatan yang akan membawa kita kepada ide yang dicita-citakan. ${ }^{11}$ Berdasarkan kronologis perkembangan kebijakan otonomi daerah, terus terjadi pergantian undang-undang yang mengatur Pemerintahan Daerah. Setiap UndangUndang Pemerintahan Daerah tersebut memiliki ciri dan karakteristik yang berbedabeda satu sama lain sehingga memberikan formulasi pengaturan dalam penyelenggaraan pemerintahan daerah di Indonesia dan merupakan norma hukum

hukum.

7 Diantha, I. Made Pasek, Metodologi penelitian hukum normatif dalam justifikasi teori

(Jakarta Prenada Media, 2016), hlm. 8.

8 Jazim Hamidi, Optik Hukum Peraturan Daerah Bermasalah, (Malang: Prestasi Pustaka Publisher), 2011, hlm 18.

${ }_{9}$ Andi Mustari Pide, Pemerintahan Daerah di Indonesia: Gerak Memusat-Daerah dalam Interaksi Konstitusi dan Politik: Kontekstualisasi Pemikiran Sri Soemantri, 2016, hlm. 136.

10 Ni'matul Huda, Otonomi Daerah (Filosofi, Sejarah Perkembangan dan Problematika), Pustaka Pelajar, Yogyakarta, 2009, hlm. 60.

11 Sunaryati Hartono, Politik Hukum Menuju Satu Sistem Hukum Nasional. Penerbit, Alumni, Bandung 1991, hlm 11. 
statis atau norma hukum umum sehingga dapat ditarik menjadi norma khusus atau lebih dikenal dengan adagium "lex specialis derogate legi generalis.". ${ }^{12}$

\subsection{Pokok-Pokok Pemerintahan Daerah Periode Orde Baru I}

Undang-Undang Nomor 1 Tahun 1957 dan Undang-Undang Nomor 18 Tahun 1965 mempunyai persamaan mendasar yang bermaksud melaksanakan prinsip otonomi yang seluas-luasnya kepada daerah. Akan tetapi, keseluruhan urusan yang diselenggarakan oleh daerah otonomi pada dasarnya bersumber dari penyerahan urusan dari pusat, jadi inisiatif daerah dalam mengurus urusan tertentu hampir dapat dikatakan tidak ada. Sebagai realisasi dari ketentuan yang memberikan pemusatan kewenangan pemerintahan daerah pada kepala daerah, tentu kepala daerah menjadi pusat daya upaya kegiatan Pemerintah Daerah yang bergerak di bidang urusan rumah tangga daerah dan menjadi mata rantai yang kuat dalam organisasi pemerintah pusat. Artinya kewenangan DPRD tidaklah begitu penting, karena UU tersebut menganggap DPRD bukanlah pemegang kekuasaan yang utama dalam penyelenggaraan pemerintah daerah. Kewenangan yang telah diberikan diketahui tidak akan mengubah titik sentral atau pengendali kekuasaan pemerintahan daerah yang melekat pada diri kepala daerah, maksudnya kedudukan dan kewenangan DPRD tidak lebih dari sekedar formalitas belaka atau pelengkap demokrasi.

\subsection{Pokok-Pokok Pemerintahan Daerah Periode Orde Baru II}

Dalam Undang-Undang Nomor 5 Tahun 1974 tentang Pemerintahan Daerah yang dimaksud dengan Pemerintah Daerah terdiri dari Kepala Daerah dan DPRD. Konstruksi tercermin bahwa UU ini sebenarnya lebih mengutamakan Kepala Daerah ketimbang DPRD. Hal itu terlihat dari penempatan Pasal 13 ayat 1, asumsi yang demikian ternyata tidak jauh berbeda dengan kesimpulan yang dikemukakan Bagir Manan tentang susunan pemerintahan daerah yaitu : Pertama, Kepala Daerah adalah alat kelengkapan utama pemerintahan daerah otonom bukan DPRD. Kedua, baik ditinjau dari fungsi, pengangkatan dan pencalonan serta wewenang yang ada, Kepala Daerah lebih mencerminkan sebagai alat (wakil) pemerintahan pusat daripada sebagai alat kelengkapan daerah otonom. ${ }^{13}$ Apabila ditinjau dalam rangka hubungan antara pusat dan daerah, kecenderungan pada sentralisasi lebih kuat daripada desentralisasi. Sebagaimana telah diketahui, berbeda dengan kedua Undang-Undang Pemerintahan di Daerah yang terdahulu (Undang-Undang Nomor 1 Tahun 1957 dan UndangUndang Nomor 18 Tahun 1965), Undang-Undang Nomor 5 Tahun 1974 tidak menyebut secara eksplisit sistem otonomi yang dianutnya. Kedua Undang-Undang terdahulu dimaksud menyatakan diri menganut sistem otonomi riil. Nyatanya didalami dalam praktik lapangan Undang-Undang Nomor 5 Tahun 1974 menganut sistem otonomi materiil. Dari sekian banyak kewenangan DPRD di Undang-Undang Nomor 5 Tahun 1974 ternyata DPRD sebagai lembaga perwakilan memiliki tiga fungsi utama yaitu perundang-undangan, anggaran, dan pengawasan. Namun ada yang berpendapat bahwa fungsi DPRD diklasifikasikan menjadi empat jenis yaitu : fungsi

12 Maria Farida, Ilmu Perundang-Undangan (Jenis, Fungsi, dan Materi Muatan), (Yogyakarta: PT. Kanisius) 2007, hlm. 20.

13 Bagir Manan, Pertumbuhan dan Perkembangan Konstitusi Suatu Negara, Mandar Maju Bandung, 1995, hlm. 241. 
perwakilan, fungsi peraturan, fungsi pengawasan, dan fungsi memilih. ${ }^{14}$ Kelemahan terjadi dikarenakan tidak berjalananya fungsi tersebut, akibat kualitas dari anggota DPRD masih sangat rendah, khususnya dari segi pendidikan dan pengalaman, dan serta sistem pemilihan atau prosedur untuk menjadi anggota.

\subsection{Pemerintahan Daerah Periode Reformasi I}

Latar belakang Undang-undang Nomor 22 Tahun 1999 tentang Pemerintahan Daerah bermula dari tuntutan reformasi atas pelaksanaan demokrasi dari pusat hingga daerah yang saat itu sudah menginginkan perubahan. Perubahan yang diinginkan untuk daerah khususnya berupa pelaksanaan otonomi daerah yang seluas-luasnya, berperannya masyarakat, dan tegaknya supremasi hukum. Perubahan mendasar dimaksud menyangkut : 1 . Asas-asas penyelenggaraan pemerintahan daerah; 2 . Pembagian wilayah; 3. Pembagian kewenangan antara pusat, daerah provinsi dan daerah Kabupaten/Kota; 4. Sistem Otonomi Daerah; 5. Susunan pemerintahan daerah; 6. Keuangan daerah; 7. Mekanisme pencalonan, pemilihan, pengangkatan, pertanggungjawaban, pemberhentian kepala daerah; 8. Mekanisme pembinaan dan pengawasan; 9. Prosedur penyusunan peraturan daerah dan keputusan kepala daerah; 10. Keuangan daerah serta penyatuan tentang pemerintahan desa dan kelurahan dengan pemerintahan daerah. Undang-Undang Nomor 22 Tahun 1999 dikaitkan dengan sistem otonomi, tampak bahwa undang-undang tersebut menganut sistem rumah tangga material dan sistem rumah tangga riil/nyata. ${ }^{15}$ Dalam undang-undang ini kepala daerah beserta perangkat daerah otonomi yang lain dianggap sebagai Badan Eksekutif Daerah, sementara DRPD disebut sebagai Badan Legislatif Daerah. Diketahui dalam melaksanakan fungsinya secara optimal, di undang-undang ini memberikan kewenangan ke DPRD diantaranya : a. Memilih Gubernur atau Wakil Gubernur, Bupati atau Wakil Bupati, dan Walikota atau Wakil Walikota; b. Memilih anggota Majelis Permusyawaratan Rakyat (MPR) dari utusan daerah; c. Mengusulkan pengangkatan dan pemberhentian Gubernur atau Wakil Gubernur, Bupati atau Wakil Bupati, dan Walikota atau Wakil Walikota; d. Bersama dengan Gubernur, Bupati, atau Walikota membentuk peraturan daerah; e. Bersama dengan Gubernur, Bupati, atau Walikota menetapkan anggaran pendapatan dan belanja daerah; f. Melaksanakan pengawasan (fungsi pengawasan atau kontrol); g. Memberikan pendapat dan pertimbangan kepada pemerintah terhadap rencana perjanjian internasional yang menyangkut kepentingan daerah; dan $h$. Menampung dan menindaklanjuti aspirasi daerah dan masyarakat. ${ }^{16}$

\subsection{Pemerintahan Daerah Periode Reformasi II}

Undang-Undang Nomor 32 Tahun 2004 mengatur dan mengurus urusan pemerintahan menurut asas otonomi dan tugas pembantuan (medebewind), agar mempercepat terwujudnya kesejahteraan masyarakat melalui peningkatan pelayanan, pemberdayaan dan peran serta masyarakat, serta peningkatan daya saing daerah dengan memperhatikan prinsip demokrasi, pemerataan, keadilan, keistimewaan, dan

\footnotetext{
14 Juanda, Hukum Pemerintahan Daerah, PT. Alumni Bandung, 2008, hlm. 188.

15 Bachsan Mustafa, Sistem Hukum Administrasi Negara Indonesia, PT.Citra Aditya Bakti, Bandung, 2001, hlm. 126.

16 Juanda, Hukum Pemerintahan Daerah, PT. Alumni Bandung, 2008, hlm. 193.
} 
kekhasaan suatu daerah dalam sistem Negara Kesatuan Republik Indonesia. ${ }^{17}$ Apa yang dinyatakan Jimly Asshiddiqie, bahwa paradigma praktis otonomi daerah adalah tidak hanya memiliki konsepsi ideal penyerahan kewenangan pusat untuk diatur oleh daerah secara otonom. Namun juga perlu adanya inisiatif yang berasal dari daerah kepada Pemerintah Pusat, guna mendorong pelaksanaan otonomi daerah. ${ }^{18}$ Dalam peraturan ini DPRD tidak lagi memilih kepada daerah, juga tidak bisa meminta pertanggungjawaban kepala daerah karena kepala daerah bertanggung jawab kepada pemerintah pusat (Presiden), kepada DPRD hanya menyampaikan keterangan pertanggungjawaban. Dengan demikian DPRD tidak lagi dapat leluasa mengkoreksi kebijakan kepala daerah yang bisa berakibat pemberhentian kepala daerah. Kemudian terjadi perubahan (pemangkasan) wewenang yang dimiliki DPRD tentu merupakan proses memperkuat esensi demokrasi yang bersistem presidensial sehingga rakyat diberikan kepercayaan secara langsung untuk menentukan pilihannya terhadap pemimpinnya baik yang ada di tingkat daerah maupun di tingkat pusat, termasuk menentukan pilihan wakil-wakilnya yang akan duduk sebagai anggota MPR, DPR, dan DPD. Berdasarkan Undang-Undang Nomor 32 Tahun 2004 memang terlihat adanya perubahan ke arah membangun hubungan keseimbangan, kesetaraan, dan kemitraan antara DPRD dan Kepala Daerah dengan dihapusnya kewenangan DPRD memilih Kepala Daerah dan dicabutnya hak DPRD meminta pertanggungjawaban dari para Kepala Daerah. Dan yang lebih terpenting yaitu terbangunnya prinsip good governance dan good government menuju clean government.

\subsection{Pemerintahan Daerah Periode Reformasi III}

Undang-Undang Nomor 23 Tahun 2014 mengatur klasifikasi urusan pemerintahan terdiri atas urusan pemerintah absolut, urusan pemerintah konkuren, dan urusan pemerintahan umum. Urusan pemerintahan absolut menyangkut hal politik luar negeri, pertahanan, keamanan, yustisi, moneter, fiskal nasional, dan agama. Penyelenggaraan urusan pemerintahan absolut dilaksanakan sendiri oleh pemerintahan pusat atau melimpahkannya kepada instansi vertikal yang ada di daerah atau gubernur sebagai wakil pemerintah pusat berdasarkan asas dekonsentrasi. Kewenangan Kepala Daerah dan DPRD, dijelaskan pada ketentuan Pasal 65 UndangUndang Nomor 9 Tahun 2015 tentang Pemerintahan Daerah, Kepala Daerah dalam menjalankan pemerintahan daerah mempunyai tugas dan wewenang : a. Memimpin pelaksanaan Urusan Pemerintahan yang menjadi kewenangan Daerah berdasarkan ketentuan peraturan perundang-undangan dan kebijakan yang ditetapkan bersama DPRD; b. Memelihara ketenteraman dan ketertiban masyarakat; c. Menyusun dan mengajukan rancangan Perda tentang RPJPD dan rancangan Perda tentang RPJMD kepada DPRD untuk dibahas bersama DPRD, serta menyusun dan menetapkan RKPD; d. Menyusun dan mengajukan rancangan Perda tentang APBD, rancangan Perda tentang perubahan APBD, dan rancangan Perda tentang pertanggungjawaban pelaksanaan APBD kepada DPRD untuk dibahas bersama; e. Mewakili Daerahnya di

17 Jurnal : Pusat Studi Hukum Dan Masyarakat Fakultas Ilmu Sosial Dan Politik Universitas Maritim Raja Ali Haji, hlm. 38.

18 Jimly Asshiddiqie, Konstitusi dan Konstitusionalisme, (Jakarta: Sinar Grafika), 2011, hlm. $217-218$ 
dalam dan di luar pengadilan, dan dapat menunjuk kuasa hukum untuk mewakilinya sesuai dengan ketentuan peraturan perundang-undangan; $f$. dihapus; g. melaksanakan tugas lain sesuai dengan ketentuan peraturan perundang-undangan. Kemudian dalam melaksanakan tugas tersebut, kepala daerah juga memiliki wewenang sebagai berikut : a. Mengajukan rancangan Perda; b. Menetapkan Perda yang telah mendapat persetujuan bersama DPRD; b. Menetapkan Perkada dan keputusan kepala daerah; c. Mengambil tindakan tertentu dalam keadaan mendesak yang sangat dibutuhkan oleh Daerah dan/atau masyarakat; dan d. Melaksanakan wewenang lain sesuai dengan ketentuan peraturan perundang-undangan. Selanjutnya untuk Dewan Perwakilan Rakyat Daerah mempunyai Fungsi dan Hak. Fungsi Dewan Perwakilan Rakyat Daerah menurut Undang-Undang Nomor 23 Tahun 2014 meliputi : a. Pembentukan peraturan daerah. b. Anggaran. c. Pengawasan. ${ }^{19}$

Secara umum peraturan ini memiliki sembilan poin penegasan dalam pelaksanaan otonomi daerah dan dirasakan sebagai satu langkah kedepan atas permasalahan yang sebelumnya, langkah-langkah tersebut yaitu :20 Pertama, Pemberian otonomi yang seluas-seluasnya kepada daerah dilaksanakan berdasarkan prinsip negara kesatuan, oleh karena itu seluas apapun otonomi yang diberikan kepada daerah, tanggung jawab akhir penyelenggaraan Pemerintahan Daerah akan tetap ada ditangan Pemerintah Pusat.Kedua, Penyelenggaraan pemerintahan daerah dilaksanakan oleh DPRD dan Kepala Daerah yang diberi mandat oleh rakyat untuk melaksanakan urusan pemerintahan konkuren, atas itu DPRD dan Kepala Daerah merupakan mitra sejajar yang mempunyai fungsi berbeda. Ketiga, Adanya absolut serta konkuren serta daerah provinsi/kabupaten/kota mempunyai urusan pemerintahan masing-masing yang sifatnya tidak hierarki. Keempat, Gubernur berperan sebagai wakil pemerintah pusat di daerah. Kelima, Penataan daerah. Keenam, Perangkat daerah. Ketujuh, Keungan Daerah. Kedelapan, Peraturan Daerah. dan Kesembilan, Inovasi daerah yang siap memajukan berdasarkan keinginan serta kekhasan daerah tersebut berdasarkan inovasi yang disandarkan pada kearifan lokal.

\section{Kesimpulan}

Sistem demokrasi di daerah pernah kebablasan bahkan mengarah ke arogansi, sementara pengawasan yang lemah dari pemerintah pusat terhadap DPRD dan pemerintah daerah menambah terbengkalainya program otonomi daerah dan sistem ketatanegaraan yang tumpang tindih sehingga lahirnya penyimpangan kekuasaan (abuses of powers). Atas hal tersebut pemerintah melalui Undang-Undang Nomor 23 Tahun 2014 sebagaimana telah dirubah menjadi Undang-Undang Nomor 9 Tahun 2015 tentang Pemerintahan Daerah telah mengatur klasifikasi urusan pemerintahan terdiri atas urusan pemerintah absolut, urusan pemerintah konkuren, dan urusan pemerintahan umum. Peraturan ini menempatkan posisi Kepala Daerah dan DPRD sebagai mitra pemerintahan artinya posisi sejajar dengan fungsi berbeda menurut asas otonomi dan tugas pembantuan dengan prinsip otonomi seluas-luasnya. Dengan adanya otonomi daerah yang telah diberikan tersebut, jelas bahwasanya setiap daerah diberi kewenangan serta kebebasan yang tersistem dalam menyusun program dan

19 Lebih lanjut lihat pasal 96, pasal 97, pasal 99, pasal 100, pasal 149, pasal 150, pasal 152, pasal 153 Undang Undang Nomor 23 Tahun 2014 tentang Pemerintahan Daerah. 
mengajukannya kepada pemerintahan pusat. Oleh karena itu, tujuan diaturnya pemerintahan daerah diharapkan akan memberikan kemandirian kepada daerah untuk mengurus rumah tangganya sendiri dan mampu membangun pertumbuhan ekonomi dalam rangka mewujudkan kesejahteraan rakyat yang bersandarkan pada amanat UUD 1945 sebagai konsekuensi dari segi pelaksanaan atas pemerintahan berdasarkan pengaturan, pelayanan, pembangunan, pemberdayaan, dan perlindungan yang berkualitas menuju negara kesejahteraan (welfare state) dalam penyelenggaraan pemerintahan daerah.

\section{Daftar Pustaka}

Buku

Ari Dwipayana, Arah dan Agenda Reformasi DPRD: Memperkuat Kedudukan dan Kewenangan Dewan Perwakilan Rakyat Daerah, (Jakarta: USAID, 2008).

Bachsan Mustafa, Sistem Hukum Administrasi Negara Indonesia, PT.Citra Aditya Bakti, Bandung, 2001.

Bagir Manan, Pertumbuhan dan Perkembangan Konstitusi Suatu Negara, Mandar Maju Bandung, 1995.

Diantha, I. Made Pasek, Metodologi penelitian hukum normatif dalam justifikasi teori hukum. (Jakarta Prenada Media) 2016.

Maria Farida, Ilmu Perundang-Undangan (Jenis, Fungsi, dan Materi Muatan), (Yogyakarta: PT. Kanisius) 2007.

Nurul Qamar,. Hak Asasi Manusia dalam Negara Hukum Demokrasi, Sinar Grafika, Jakarta Timur, 2013.

Jimly Asshiddiqie, Perihal Undang-Undang, Rajawali Pres, Jakarta, 2011.

Jimly Asshiddiqie, Konstitusi dan Konstitusionalisme, (Jakarta: Sinar Grafika), 2011.

Jazim Hamidi, Optik Hukum Peraturan Daerah Bermasalah, (Malang: Prestasi Pustaka Publisher), 2011.

Juanda, Hukum Pemerintahan Daerah, PT. Alumni Bandung, 2008.

Ni'matul Huda, Otonomi Daerah (Filosofi, Sejarah Perkembangan dan Problematika), Pustaka Pelajar, Yogyakarta, 2009.

Pide, Andi Mustari. Pemerintahan Daerah di Indonesia: Gerak Memusat-Daerah dalam Interaksi Konstitusi dan Politik: Kontekstualisasi Pemikiran Sri Soemantri, Bandung: Pusat Studi Kebijakan Negara Fakultas Hukum Universitas Padjadjaran (PSKN FH UNPAD), 2016.

Sunaryati Hartono, Politik Hukum Menuju Satu Sistem Hukum Nasional. Penerbit, Alumni, Bandung 1991.

\section{Jurnal}

Ahmad Dahlan dan Santosa Irfan, Menggagas Negara Kesejahteraan, Jurnal el-Jizya, II no. 1 (2014).

Neta, Yulia. "Model Tata Kelola Administrasi Pemerintahan Yang Baik di Daerah Otonom Baru." FIAT JUSTISIA: Jurnal Ilmu Hukum 6, no. 2 (2014).

Saragih, Jopinus. "Reformasi Aparatur Negara untuk Melaksanakan Tata Kelola Pemerintahan yang Baik dan Benar (Good Governance)." Jurnal Ilmiah Widya (2012): 218756.

\section{Makalah/laporan}

Pusat Studi Hukum Dan Masyarakat Fakultas Ilmu Sosial Dan Politik Universitas Maritim Raja Ali Haji. 


\section{Peraturan Perundangan}

Undang-Undang Nomor 18 Tahun 1965 tentang Pokok-Pokok Pemerintahan Daerah. Undang-Undang Nomor 5 Tahun 1974 tentang Pokok-Pokok Pemerintahan Daerah. Undang-Undang Nomor 22 Tahun 1999 tentang Pemerintahan Daerah. Undang-Undang Nomor 32 Tahun 2004 tentang Pemerintahan Daerah. Undang Undang Nomor 23 Tahun 2014 tentang Pemerintahan Daerah. Undang-Undang Nomor 9 Tahun 2015 tentang Pemerintahan Daerah. 